\title{
Karyotype morphology and evolution in some Lathyrus (Fabaceae) species of southern Brazil
}

\author{
Adriane Klamt and Maria Teresa Schifino-Wittmann
}

\begin{abstract}
The karyotypes of Lathyrus nervosus Lam., L. pubescens Hook. et Arn., L. paranensis Burk. and L. crassipes Gill ap. Hook et Arn., native to Rio Grande do Sul (southern Brazil), are described in detail for the first time. All taxa have $2 \mathrm{n}=14$ chromosomes. The karyotypic formulae were $2 \mathrm{~m}+12 \mathrm{sm}$ for L. nervosus, L. pubescens and L. paranensis and $4 \mathrm{~m}+10 \mathrm{sm}$ for L. crassipes. In all species, the smallest chromosome pair bore a secondary constriction with a satellite in the long arm. Intraspecific variability in the position and number of secondary constrictions was observed in L. nervosus and L. pubescens. All of the species had a conservative and similar karyotype morphology, but differed in total complement size by as much as $20 \%$ between the highest (L. nervosus) and lowest ( $L$. crassipes) values. These results suggest that changes in chromosome size during evolution have been similar for all the chromosomes of the complement. Together with data on the life cycle and mode of reproduction, these results also indicate that $L$. crassipes is a derived taxon, if an evolutionary trend towards a decrease in chromosome size is accepted.
\end{abstract}

\section{INTRODUCTION}

The genus Lathyrus (Fabaceae, Papilionoideae, Vicieae) comprises nearly 150 species of annual and perennial, autogamous and allogamous herbaceous creeping plants, which occur throughout the temperate regions of the Northern Hemisphere and South America. The main centers of diversity are the Mediterranean region, Asia Minor and North America, as well as temperate South America and East Africa (Kupicha, 1977, 1981; Jackson and Yunus, 1984; Yamamoto et al., 1984; Simola, 1986). There are two hypotheses for the colonization of the Americas by this genus: during the Tertiary, when Africa and South America were still united (Simola, 1986), or between the Cretaceous and the Paleocene, through Greenland and Alaska (Kupicha, 1983). In South America, Lathyrus species are found from Colombia to Tierra del Fuego, having probably migrated to the austral part of the continent by the Andean route (Burkart, 1935).

The 23 Lathyrus species endemic to South America were included in the section Notholathyrus Kupicha by Kupicha (1983). Of these, 12 (L. crassipes Gill ap. Hook. et Arn., L. hasslerianus Burk., L. hookeri G. Don., L. linearifolius Vog., L. macrostachys Vog., L. nervosus Lam., L. nitens Vog., L. paranensis Burk., L. paraguariensis Hass., L. parodii Burk., L. pubescens Hook. et Arn., and $L$. subulatus Lam.) occur in Rio Grande do Sul, the southernmost state of Brazil (Neubert, E., personal communication). Since many species are potentially good forage resources, the characterization and conservation of their germplasm is desirable.
Although many North American and European species of the genus are well known, there are few studies of South American taxa; however, some work has been carried out on their cytogenetics (Battistin and Fernandez, 1994; Schifino-Wittmann et al., 1994) and isozymes (Gonzalez and Schifino-Wittmann, 1996). In this paper we present a detailed karyotypic study of several populations of four Lathyrus species native to Rio Grande do Sul. This information is useful for germplasm characterization and for plant breeding and may improve our understanding of the evolution of the genus.

\section{MATERIAL AND METHODS}

Thirty-eight accessions of four Lathyrus species were evaluated (Table I). Seeds from 12 accessions of $L$. nervosus, 10 of $L$. pubescens, 6 of L. paranensis and 10 of $L$. crassipes were collected in several regions of Rio Grande do Sul and one accession each of L. nervosus and L. pubescens from Uruguay ( $28-35^{\circ}$ latitude South). The maternal plants were kept as taxonomic vouchers.

L. nervosus is a perennial. Stems reach up to $40-60$ $\mathrm{cm}$; the inflorescences bear 3 to 10 bluish flowers. This species is characterized by highly innervated stipules. It is normally found along roadsides, near woods, and sometimes in open fields. It flourishes in spring and summer.

L. pubescens is a robust perennial. Stems reach up to $1 \mathrm{~m}$, the inflorescences bear six to 16 bluish flowers. It is more easily found along roadsides and river margins and flourishes in spring.

L. paranensis is an herbaceous annual. Stems reach 
from 0.3 to $1 \mathrm{~m}$, the inflorescences bear three to nine big bluish-violet flowers. The plant becomes completely black when dried. It grows in flooded or very humid places, and flourishes in summer.

L. crassipes is a small annual. Stems are thin and reach from 10 to $60 \mathrm{~cm}$. The inflorescences bear one to three small white-bluish flowers. It is a morphologically variable species, normally found in open fields and along roadsides, and flourishes in spring.

L. crassipes is very common and widely distributed in Rio Grande Sul. L. nervosus and L. pubescens also have a wide range of distribution. L. paranensis is characteristic of the swamps of the Campos de Cima da Serra region of Rio Grande do Sul.

These four species were selected due to the ready availability of seeds, as they were frequently found during collection expeditions. The seeds were scarified with sandpaper and germinated on Petri dishes lined with moist filter paper at room temperature. Root tips $2 \mathrm{~mm}$ long were pre-

Table I - Lathyrus accessions examined in Rio Grande do Sul State.

\begin{tabular}{|c|c|c|}
\hline Species & Accession & Collection site \\
\hline \multirow[t]{12}{*}{ L. nervosus } & S Farol 1 & Torres \\
\hline & S Farol 2 & Torres \\
\hline & S Guarita 2 & Torres \\
\hline & S Guarita 4 & Torres \\
\hline & M 1206 & Porto Alegre \\
\hline & M 1388 & Caçapava do Sul \\
\hline & IB s $/ n^{1}$ & Vacaria \\
\hline & W 11 & Pedro Osório \\
\hline & W 5 & Caçapava do Sul \\
\hline & K 58 & São Sepé \\
\hline & Zago/Bagé $^{1}$ & Rio Camaqua \\
\hline & NI 7045 & Piriapolis, Uruguay \\
\hline \multirow[t]{10}{*}{ L. pubescens } & Zago/Caçapava & Caçapava do Sul \\
\hline & Zago/Caieira & Caçapava do Sul \\
\hline & Zago/Bagé ${ }^{2}$ & Bagé \\
\hline & K61 & Caçapava do Sul \\
\hline & IB $s / n^{2}$ & Vacaria \\
\hline & S 1034 & Caçapava do Sul \\
\hline & W 02 & Caçapava do Sul \\
\hline & W 13 & Caçapava do Sul \\
\hline & ZM 817 & Caçapava do Sul \\
\hline & Kyiu & San José, Uruguay \\
\hline \multirow[t]{6}{*}{ L. paranensis } & K08 & São Francisco de Paula \\
\hline & K 14 & São Francisco de Paula \\
\hline & K 23 & São Francisco de Paula \\
\hline & K33 & São Francisco de Paula \\
\hline & K35 & São Francisco de Paula \\
\hline & $\mathrm{K} 41$ & São Francisco de Paula \\
\hline \multirow[t]{10}{*}{ L. crassipes } & Ana Celina & Porto Alegre \\
\hline & Zago/Caçapava & Caçapava do Sul \\
\hline & Zago/Pedro Osório & Pedro Osório \\
\hline & Zago 244 & Caçapava do Sul \\
\hline & K 62 & Picada Café \\
\hline & $\mathrm{S} \mathrm{s} / \mathrm{n}$ & Porto Alegre \\
\hline & S 995 & Porto Alegre \\
\hline & M 1159 & Santiago \\
\hline & M 1425 & São Gabriel \\
\hline & W 12 & Caçapava do Sul \\
\hline
\end{tabular}

treated with a saturated solution of paradichlorobenzene at $4^{\circ} \mathrm{C}$ for $18-20 \mathrm{~h}$, fixed in absolute ethanol:glacial acetic acid (3:1) for $12-24 \mathrm{~h}$ and stored in $70 \%$ ethanol at $4^{\circ} \mathrm{C}$ until required. Prior to analyses, the seeds were washed in distilled water, transferred to a solution of one part of cellulase ( 0.3 units $/ \mathrm{mg}$ ) and 10 parts of pectinase ( 11.8 units/ $\mathrm{mg}$ ) for $40 \mathrm{~min}$, hydrolyzed in $5 \mathrm{~N} \mathrm{HCl}$ for $15 \mathrm{~min}$ and squashed and stained in propionic carmine for $25 \mathrm{~min}$. Semipermanent slides were examined by light microscopy.

Chromosomal measurements were made from photographs of 10 well-spread metaphase plates per plant. Short arm length (s), long arm length (l) and centromeric indices $(\mathrm{CI}=\mathrm{s} / \mathrm{s}+\mathrm{l})$ were determined. The classification of chromosomes by centromeric indices followed Levan et al. (1964). Total haploid complement length (TCL) was also calculated. Homologous chromosomes were paired by length, centromeric index and presence and location of secondary constrictions and satellites. Comparative idiograms were constructed from the average chromosome length, centromeric index and TCL for each accession and each species. TCL values for all accessions and species were compared using analysis of variance.

\section{RESULTS AND DISCUSSION}

All species were diploid, with $2 \mathrm{n}=14$ chromosomes. This agrees with previous studies of Lathyrus species, including South American taxa (Federov, 1969; Kupicha, 1983; Yamamoto et al., 1984; Broich, 1989; Battistin and Fernandez, 1994; Schifino-Wittmann et al., 1994). Polyploidy is uncommon in the genus (Federov, 1969) and all known species in the section Notholathyrus are diploid.

L. nervosus (Figures 1A and 2) had a karyotypic formula of $2 \mathrm{~m}+12 \mathrm{sm}$. This species had the biggest chromosomes and the highest TCL of the species studied (Table II). The first and largest pair was metacentric. The other six were submetacentric and very similar in size and centromeric indices. Pair 7, the smallest of the complement, bore a conspicuous secondary constriction and a satellite in the long arm. This constriction was probably the nucleolar organizing region, as shown by NOR-staining (Battistin and Fernandez, 1994). One accession (Farol 1) presented two chromosome pairs with secondary constrictions while another accession (W 11) had a heteromorphic satellite-bearing pair, probably the result of a pericentric inversion.

L. pubescens (Figures 1B and 2) had a karyotypic formula of $2 \mathrm{~m}+12 \mathrm{sm}$. The karyotype morphology was similar to that of $L$. nervosus. The satellite pair was also the smallest of the complement. There was polymorphism in the number and position of the secondary and other constrictions. One accession (IB s/n $\mathrm{n}^{2}$ ) had proximal and terminal constrictions in the short arm of the second pair of chromosomes; another (Zago/Bagé2) had proximal constrictions in the short arm of the first pair. Accession ZM 817 differed from the other L. pubescens accessions by 

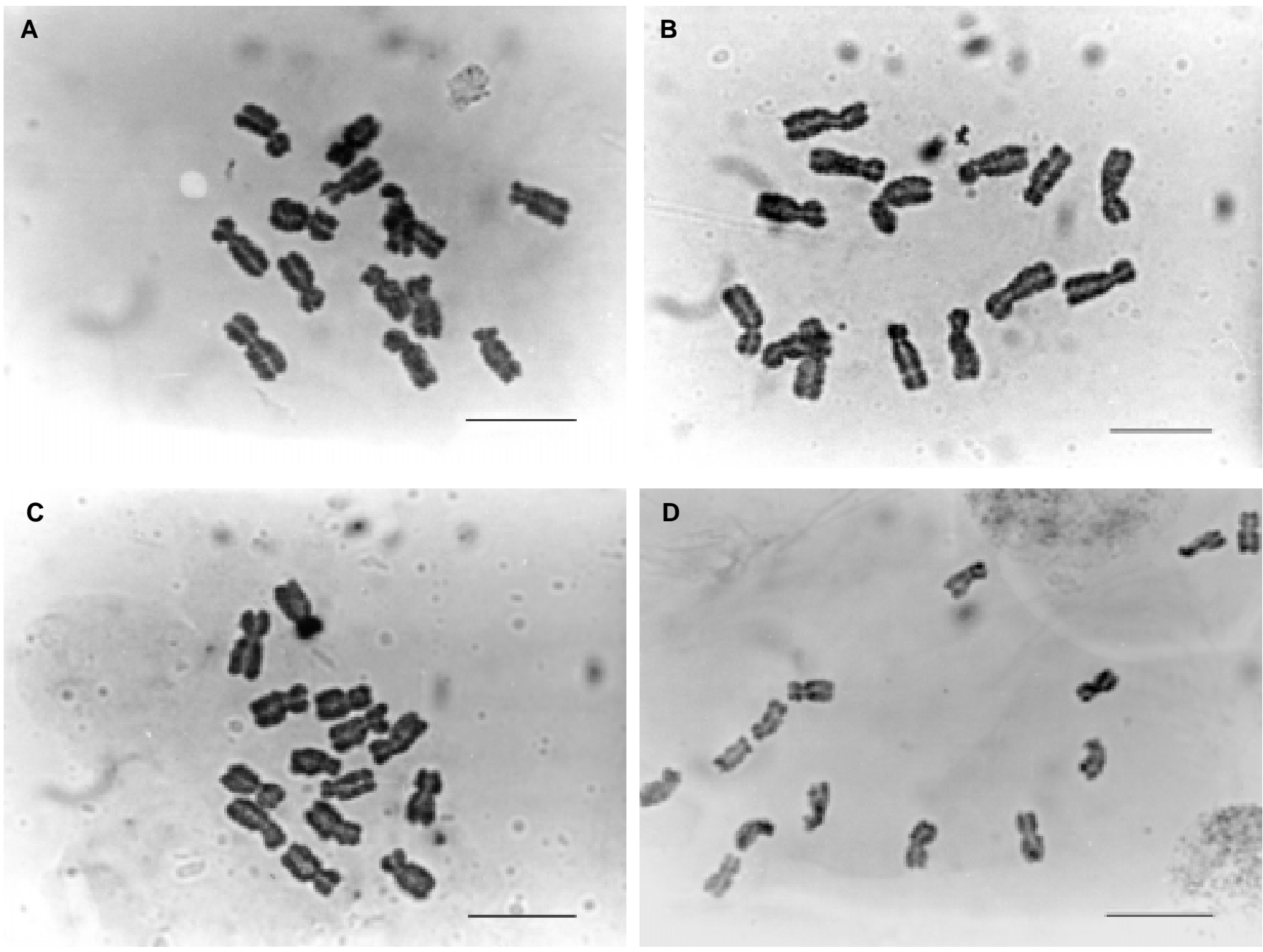

Figure 1 - Metaphase plates of Lathyrus nervosus (A), L. pubescens (B), L. paranensis (C) and L. crassipes (D). Scale: $10 \mu \mathrm{m}$.

the relative size of the satellite pair, being placed as sixth in length. This difference was consistent in all the cells analyzed and reflects a biological characteristic rather than a technical problem.

The extraconstrictions in L. nervosus and L. pubescens may be NORs as suggested by Murray et al. (1992a,b) for other Lathyrus species. Battistin and Fernandez (1994) described similar karyotypic formulae for L. nervosus and $L$. pubescens but different TCL values and positions of satellited chromosomes. This discrepancy most likely reflects the small sample size (plants and cells) used by the latter authors.

The intraspecific variation found for the number of secondary constrictions in $L$. nervosus and L. pubescens and for the size of the satellite pair in accession ZM 817 of $L$. pubescens is not related to any apparent difference in morphology, from examination of the herbarium vouchers (Miotto, S., personal communication). The collection locations were not the same as for the other accessions (Table I) but there is no evidence of any relation to special ecological differences (Miotto, S., personal communica- tion). This polymorphism most likely reflects simple intraspecific variability.

L. paranensis (Figures 1C and 2) had a karyotypic formula of $2 \mathrm{~m}+12 \mathrm{sm}$, identical to that of L. nervosus and $L$. pubescens. The smallest chromosome pair bore a secondary constriction.

L. crassipes (Figures 1D and 2) had a karyotypic formula of $4 \mathrm{~m}+10 \mathrm{sm}$. This karyotype was easily distinguished from that of $L$. nervosus, $L$. pubescens and $L$. paranensis as the chromosomes were smaller (Table II). The first and third pairs were metacentric. The secondary constriction was located on the smallest pair of the complement. There were significant differences in TCL (Table II) between the species.

These Lathyrus species had similar karyotypes, although chromosome size was a diagnostic characteristic in at least one case ( $L$. crassipes). There was symmetrical variation in the size of the chromosomes in the different species, suggesting that equal amounts of DNA had been lost (or acquired) by all the chromosomes. Narayan and Durrant (1983) suggested that an approximately equal in- 

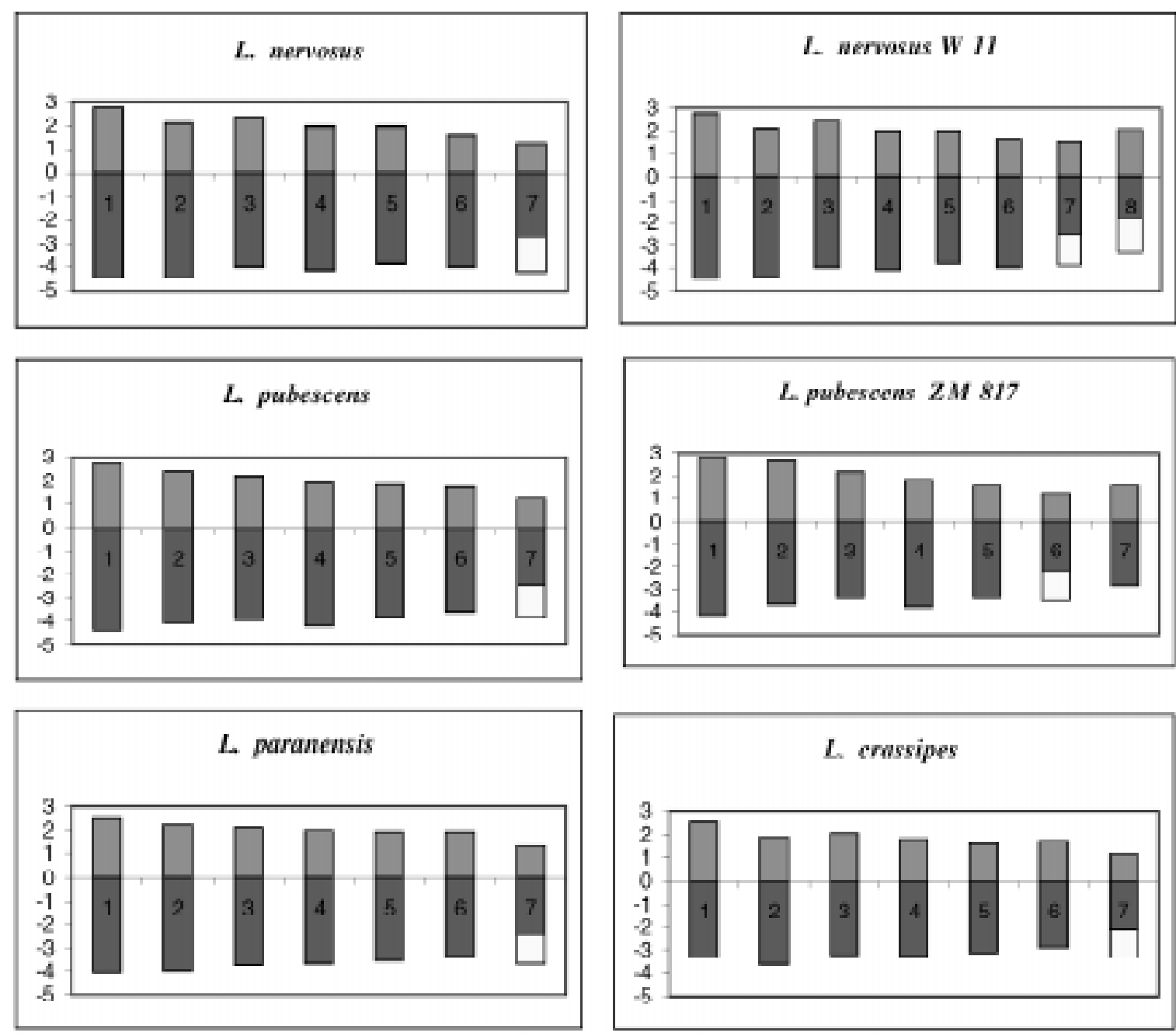

Figure 2 - Idiograms of the four Lathyrus species, showing the polymorphism in L. nervosus and L. pubescens. In L. nervosus $\mathrm{W} 11$ the chromosomes numbered 7 and 8 represent the polymorphism of the satellited pair. Vertical scale in $\mu \mathrm{m}$.

Table II - Average chromosome lengths in $\mu \mathrm{m}(\mathrm{L})$, centromeric indices (CI) and total complement length (TCL) of four Lathyrus species.

\begin{tabular}{|llllllllllll|}
\hline Species & & \multicolumn{8}{c|}{ Chromosome pairs } & & $\begin{array}{c}\text { TCL } \\
(\mu \mathrm{m})\end{array}$ \\
\cline { 3 - 8 } & & 1 & 2 & 3 & 4 & 5 & 6 & 7 & \\
\hline \multirow{2}{*}{ L. nervosus } & $\mathrm{L}$ & $7.3^{*}$ & 6.5 & 6.4 & 6.1 & 5.8 & 5.6 & 5.4 & 42.9 \\
& $\mathrm{C}$ & 0.38 & 0.32 & 0.37 & 0.33 & 0.34 & 0.29 & 0.31 & \\
L. pubescens & $\mathrm{L}$ & 7.0 & 6.5 & 6.1 & 6.1 & 5.6 & 5.3 & 5.1 & 41.3 \\
& $\mathrm{CI}$ & 0.38 & 0.37 & 0.36 & 0.31 & 0.32 & 0.32 & 0.33 & \\
L. paranensis & $\mathrm{L}$ & 6.5 & 6.2 & 5.9 & 5.7 & 5.5 & 5.3 & 5.0 & 40.0 \\
& $\mathrm{CI}$ & 0.38 & 0.35 & 0.36 & 0.35 & 0.35 & 0.36 & 0.35 & \\
L. crassipes & $\mathrm{L}$ & 5.9 & 5.5 & 5.3 & 5.1 & 4.8 & 4.6 & 4.4 & 35.5 \\
& $\mathrm{CI}$ & 0.43 & 0.34 & 0.38 & 0.35 & 0.33 & 0.37 & 0.35 & \\
\hline
\end{tabular}

crease in the DNA content of the chromosomes of some Lathyrus species could have resulted from: a) a continuous random increase in which each chromosome had an equal chance of acquiring additional amounts of DNA; b) some mechanism to ensure that equal increments occurred irrespective of chromosome size, or c) selection against individuals with unequal increments.

Total chromosome length in perennial Lathyrus species is generally greater than for annual species (Rees and Hazarika, 1969; Yamamoto et al., 1984). A similar difference has also been found in Vicia, a closely related genus (Rees et al., 1966).

L. nervosus and L. pubescens are outbreeding perennials, L. crassipes an inbreeding annual, and L. paranensis an annual (Burkart, 1935, 1987). This has been supported by greenhouse (Klamt, A. and Schifino-Wittmann, M.I., unpublished results) and field (Boldrini, I. and Miotto, S., personal communication) observations.

Generally annual species are derived from perennial 
species and inbreeding species from outbreeding species. Our data suggest that the evolution of the Lathyrus species studied was accompanied by a decrease in chromosome size and that $L$. crassipes is a derived species. This interpretation is based on the total chromosome complement length, life cycle and mode of reproduction of the four species examined.

Lathyrus species in the section Notholathyrus are the most specialized of the genus (Kupicha, 1983). European species of the sections Pratensis, Lathyrus, Orobusrum, Cicercula, Nissolia and Aphaca generally have their satellites in the largest (first or second) chromosome pair (Yamamoto et al., 1984), while those we analyzed had satellites in the smallest pair. Since the European species are likely ancestors of the South American species, we suggest that the differences in satellite position and chromosome shape arose by karyotype rearrangements, probably involving translocations from the largest to the smallest pairs of chromosomes.

\section{ACKNOWLEDGMENTS}

The authors thank Dr. Silvia Miotto, Departamento de Botânica, Universidade Federal do Rio Grande do Sul, for the taxonomical identifications, and Dr. Eric Boa, CABI Biosciences, UK, for correcting the English manuscript.

\section{RESUMO}

Os cariótipos de Lathyrus nervosus Lam., L. pubescens Hook. et Arn., L. paranensis Burk. e L. crassipes Gill ap. Hook et Arn., quatro espécies de Lathyrus nativas do Rio Grande do Sul, são detalhadamente descritos pela primeira vez. Todos os taxa apresentaram $2 \mathrm{n}=14$ cromossomos. As fórmulas cariotípicas foram $2 \mathrm{~m}+12 \mathrm{sm}$ para $L$. nervosus, L. pubescens e L. paranensis e $4 \mathrm{~m}+10 \mathrm{sm}$ para L. crassipes. Em todas as espécies o menor par de cromossomos apresentava uma constrição secundária com um satélite no braço longo. Foi verificada variabilidade intraespecífica para posição e número de constrições secundárias em L. nervosus e L. pubescens. Todas as espécies apresentaram uma morfologia cariotípica semelhante mas diferiram no comprimento total do complemento em até $20 \%$ entre os valores mais altos para $L$. nervosus e os mais baixos para $L$. crassipes. Estes resultados sugerem que as mudanças no tamanho cromossômico ocorridas durante a evolução das espécies foram homogêneas para todo o complemento e, juntamente com in- formações sobre ciclo de vida e modo de reprodução, apoiam ser $L$. crassipes um taxon derivado, aceitando-se uma tendência evolutiva para diminuição do tamanho cromossômico.

\section{REFERENCES}

Battistin, A. and Fernandez, A. (1994). Karyotypes of four species of South America natives and one cultivated species of Lathyrus L. Caryologia 47: 325-330.

Broich, S.L. (1989). Chromosome number of North American Lathyrus (Fabaceae). Madrono 36: 41-48.

Burkart, A. (1935). Revision de las especies de Lathyrus de la Republica Argentina. Rev. Fac. Agron. Vet. Univ. B. Aires 8: 41-128.

Burkart, A. (1987). Flora Ilustrada de Entre Rios. Coleccion Cientifica del INTA, VI, INTA, Buenos Aires.

Federov, A.A. (1969). Chromosome Numbers of Flowering Plants. Academy of Science of the URSS, Leningrad.

Gonzalez, A.C. and Schifino-Wittmann, M.T. (1996). Isoenzymatic characterization of some Lathyrus L. and Vicia L. species (Leguminosae) occurring in Rio Grande do Sul (Southern Brazil). Braz. J. Genet. 19: 283-288.

Jackson, M.T. and Yunus, A.G. (1984). Variation in the grass pea (Lathyrus sativus L.) and wild species. Euphytica 33: 549-559.

Kupicha, F.K. (1977). The delimitation of the tribe Vicieae (Leguminosae) and the relationships of Cicer L. Bot. J. Linn. Soc. 74: 131-162.

Kupicha, F.K. (1981). Tribe Vicieae. In: Advances in Legume Systematics (Polhill, R.M. and Raven, P.H., eds.). Part 1. Royal Botanical Garden, Kew, pp. 377-381.

Kupicha, F.K. (1983). The infrageneric structure of Lathyrus. R. Bot. Gard. 41:209-244.

Levan, A., Fredga, K. and Sandberg, A.A. (1964). Nomenclature for centromeric position on chromosomes. Hereditas 52: 201-220.

Murray, B.G., Bennett, M.D. and Hammett, K.R.W. (1992a). Secondary constrictions and NORs of Lathyrus investigated by silver staining and in situ hybridisation. Heredity 68: 473-478.

Murray, B.G., Hammett, K.R.W. and Standring, L.S. (1992b). Constancy during the development of Lathyrus odoratus cultivars. Heredity 68: 321-327.

Narayan, R.K.J. and Durrant, A. (1983). DNA distribution in chromosomes of Lathyrus species. Genetica 61: 47-53.

Rees, H. and Hazarika, M.H. (1969). Chromosome evolution in Lathyrus. Chromosomes Today 2: 158-165.

Rees, H., Cameron, F.M., Jones, G.H. and Hazarika, M.H. (1966). Nuclear variation between diploid angiosperms. Nature 211: 828-830.

Schifino-Wittmann, M.T., Lau, A.H. and Simioni, C. (1994). The genera Vicia and Lathyrus in Rio Grande do Sul (Southern Brazil): cytogenetics of native, naturalized and exotic species. Rev. Bras. Genet. 17: 313-319.

Simola, L.K. (1986). Structural and chemical aspects of evolution of Lathyrus species. In: Lathyrus and Lathyrism (Kaul, A.K. and Combes, D., eds.). Proceedings of the International Symposium of IBEAS (1985), Paris, pp. 225-239.

Yamamoto, K., Fujiware, T. and Blumenreich, I.D. (1984). Karyotypes and morphological characteristics of some species in the genus Lahtyrus L. Jpn. J. Breed. 34: 273-284.

(Received December 14, 1998) 
